\title{
Persian Poetry and Wine in its Place
}

Ali Mamkhezri, Kamran Pashaee-Fakhri*, Parvaneh Aadelzadeh

Department of Persian Language and Literature, Tabriz Branch, Islamic Azad University, Tabriz, Iran

Corresponding Author: Kamran Pashaee-Fakhri, E-mail: pashaiekamran@yahoo.com

\section{ARTICLE INFO}

Article history

Received: May 19, 2017

Accepted: July 05, 2017

Published: December 01, 2017

Volume: 6 Issue: 7

Special Issue on Language \& Literature Advance access: September 2017

Conflicts of interest: None

Funding: None

\begin{abstract}
In the Persian literature "wine" is divided in to three sub-categories: mystic, true and literary. The true wine is used in texts, where the intention is to show the pleasures of life, whereas in some philosophical and mystic texts such as the story of Zartosht and Goshtasb, drinking wine and Haoma juice. results in achieving knowledge and cognition and being prepared for making important decisions. Sometimes it was only used ritually and not drunk and this made them to discover the unseen and unknown secrets. Therefore, on can classify the true wine- which is also called natural win - in to two groups: natural festive and natural Hikmah/philosophical wines. Basically, they differ in their usages. The first one drunk for joy and pleasure and the second one to reach knowledge and cognition.
\end{abstract}

Key words: Rationalism, Epicure, Haoma Juice, Hikmah/Philosophical Wine

\section{INTRODUCTION}

When one talks about "philosophy", he must know that one of its bases is "rationalism" and "reason". There have been many discussions and debates about the origin of mind and intellect and its position in the human's life, and different ideas have been proposed; but what all agree upon is that "mind" was originally translated from the Greek word "nous" which was regarded as the "motion source" in Greek philosophers' viewpoints. The mentioned Greek word was translated in Arabic texts as "bond and obstacle", and in Persian Literature it has been rendered to "reason" and "thought".

In religious, literary and hikmah/philosophical texts, in addition to these translations, there have been mentioned other equivalents such as the knowledge power against ignorance, the power to distinguish bad from good against lust and caprice and the power to understand and percept against believing.

The main role of reason or mind in the human's life is to recognize the truths, as "knowledge" brings forth certainty for a healthy and calm life. In order to clarify this goal, we will discuss two standpoints of rationalism and empiricism that both look upon "knowledge" through reason.

In the opinion of rationalist philosophers, "knowledge" is an interconnected system which has a certain unity and cohesion and is classified into three sections of "imaginations, verifications and reasons" that in each of these sections, a systematic order rules. The imaginations are ordered in case of priority and intensity, and then they will be merged with verifications; and finally they will form a body of reasons with certain unity. These consolidate systems cannot only be the result of empiricism and experience, and an agent power called mind should organize them (Ibid, 2005, 290). This kind of "knowledge" is of the natural and congenital basics of human being, and the philosophers believe that mankind is able to percept the truth and the true knowledge is imbedded in the human's mind. This means that the mind, is the agent and source of knowledge and it begins knowing the truth inside itself. Also, the mentioned philosophers think that knowledge is done via two instruments: sensory and rational, of which they insist on the superiority of "rational knowledge" over "sensual and empirical knowledge".

The idea of "empiricist" philosophers about "mind" is that the human mind is like a blank slate and everything is gained with experience and one can gain certitude via experiencing. This standpoint is against the "rationalist" idea and denies the innate bases of "knowledge" and claims that the mind before having any experiences, is like a blank slate or a blank paper and perceptions are gathered into the mind through experience. The empiricist philosophers also insist that anything available in the mind, is the result of senses. This means that the mind lacks any perception and imagination in itself; which is one of the heritages of Aristotelian philosophy

All the rational and empirical attempts are in order to uncover all the aspects and angles of knowledge, so that mankind could reach a certainty and mental relief, while gaining expertise in the knowledge of nature and metaphysics.

In any case, the humankind due to his short lifetime, cannot master all the general and specific areas, and will resort to "reasoning" as a way to answer the many obscure ques- 
tions; so that by this technique he would be able to clarify the intellectual, theoretical and ethical unknowns, and by gaining knowledge, he could heal his wound of ignorance.

Emotional and social break down which is resulted from mental failure, are the remarkable subject in the Persian poetry. Poets, regardless of how they think, bring forth artistic innovations in order to overcome their failures. One of the innovations, is the use of expressions which can compensate for the failure and could rehabilitate the broken mind. In order to reach this goal, words and expressions such as "love" and "wine" are used which has been a hot topic in the literature for many years. However, one of the research methods in this area is referring to different Hikmah/philosophical schools so that the human being could justify these expressions and rest assured that the reasoning and thought can be helpful.

\section{Subject}

Islam regards "reason" and "mind" with respect and admiration, and always emphasized its "position", while prohibiting man from drinking intoxicants and narcotics, so that by preventing from the disorders in the feelings and reasoning, a rule-based and healthy society is made. Hence in such society, the bliss of mankind in both worlds is provided, without any harm or regret.

Our today civilized society is consisted of different classes and groups such as authors, poets, philosophers, scientists and other intellectuals who have their own lifestyle, way of thinking and religion, due to the freedom in the society. Among them, the poets sometimes get involved in the unsettled tension between their profane interpretation of the world and the metaphysics, and they come to cul-de-sac in their minds where there is no way out. Thus in this cases, the poets resort to some sorts of "trance" in the poems, by means of which they seek to heal their pains. One of the many techniques used in this regard is the use of "figures of speech", and also unfamiliar expressions, words and phrases that distinguishes from the others.

As it was mentioned earlier, "wine" is one of the poetical words which has been used by mystic, non-mystic, humorous, serious, ridiculous, and absurd poets, resulting in the obscurity of its different meanings.

Experts in poetry, usually tend to justify and explain this issue, in order to exempt the great literary figures from the charge of "drinking wine" and preventing from their notoriety in the Islamic society. However, as there is not documentary evidence about some of these great figures, the researchers have attempted to discuss this issue, from their personal viewpoint while considering the definitions of the triple wine classification of mystical, true and figurative or literary. Nevertheless, they failed to comment on the correctness or incorrectness of the meanings in these explanation - save for some remarkable poets. In any case, when in the poetry and literature, one speaks of "drinking wine", "drunkenness" and "intoxication", can we come to this conclusion that all the obscure true wines used in the poem, were implications of leisure, drinking feasts, festivity and such things? Has anyone considered this issue that maybe the use of "wine" has been an implication for getting rid of an obscure question which has not any solid answer? Has anybody distinguished the "wine" which gives joy and pleasure from the natural and virtual ones which has been used for freeing oneself rom the unanswered issues, to which no philosopher and thinker had had any answer? Perhaps, we can answer these type of questions by means of philosophical, Hikmah and religious schools.

The thinkers and poets, use different philosophical ideas in order to answer some of these whys and riddles and as they find that "reasoning" and "experience" cannot solve these conundrums, they inevitably attempt to find an answer by going against the rational norms or by letting loose the bird of their imagination. Hence, the wine they speak in their poems, is the one which can enhance the conscience, increase the perception, overcome the ambiguities, uncovers the unknowns and enables the drinker to make right decisions. This type of "wine" must be other than the three cases of mystic, literary and true-festive. Thus, it is necessary to redefine all the four types of wine to feel the differences.

\section{Hikmah/philosophical true and virtual wine}

In order to study the meanings of "wine" in the Persian literature, we must take a look at the ancient rituals of Iran, before the Khorasani style of poetry come to existence. Although there are not many remarkable works of this era at hand; we can see this era's many Iranian customs and rituals in the few works remained in the course of history or their reflections in the whole Persian literature.

Most poets, with their unnatural feelings and emotions that is the essence of their poems and lives, are distinguishable from the normal people. They will question anything that seems to be problematic, put the axioms on trial; act against the social and political injustice and feel responsible for anything in the society. Therefore, when they cannot find an answer to a question, they will become nervous and confused, and they will turn to imagination and innovation in order to get rid of such problems, and use meanings, expressions and unfamiliar words to reduce their confusion and apprehension, maybe their minds will be calmed.

The most remarkable word that can redeem them from these "confusions" is wine with its many meanings, since this word, besides letting their thought loose, will imply what they truely mean. Of course, each poet means something and this very issue, has been problematic in the way to interpret what the poet means by "wine". In order to clarify this subject, we will look at the history of "drinking wine", so that some of the ambiguities will be eradicated.

In a book called "Iranian Culture and Religion" about the Iranian philosophy before the Prophet Zartosht in "Hom Yasht, Yansa 10", we read: "All other toxicants go hand in hand with Rapine of the bloody spear, but Haoma's stirring power goes hand in hand with friendship. [Light is the drunkenness of Haoma]. Who as a tender son caresses Haoma, forth to the bodies of such persons Haoma comes to heal. O Haoma, endow the man who drinks thee mixed with milk; yea, more prosperous thou makest him, and more 
endowed with mind. Before thee, holy Haoma, thou bearer of the ritual truth, and around thee would I cast this body, a body which (as all) may see (is fit for gift and) grown."(Razi, 2011, 175-176). Although Haoma sacred drink is of "natural and true" type of wine but it is for "mind" and perception and is not of the kind for drinking in the feasts and just for taking pleasure.

In Zartosht's philosophy and in Zand-i Vohuman Yasht's commentary (section 3, chapter 14), there is a story which is very significant and thought provoking; Zartosht requests Ohrmazd to make him immortal, but Ohrmazd answers "this is not possible, as it is written that you must be killed by Tur-i Bratrush the Karp, and if you become immortal then it will not be possible to perform the resurrection and the final-most material existence. Then Zartosht remains thoughtful for a while. Ohrmazd lays the wisdom of all knowledge, in the form of water, on the hand of Zartosht; and He said "Drink forth". And forth Zartosht drank it; thereupon, the wisdom of all-knowledge intermingled into Zartosht. For seven days and nights, Zartosht was in the wisdom of Ohrmazd. Thereupon, Zartosht beheld men and animals in the seven regions of the earth. On the seventh day and night, He took away the wisdom of all-knowledge from Zartosht. After this incident, Zartosht comes an intuition. This story has been interpreted by the Magus and Zoroastrian priests in another form: when Goshtasb asks Zartosht to show him the other world, Zartosht gives him a mixture of wine and Bhang, which is known as Goshtasbian Bhang or Mang. Also when Ardaviraf, is ordered to get knowledge about the heaven and the hell in the magus gathering, by going on some sort of trance and leaving his body, he drinks a mixture of wine and bhang and remains in trance mood for seven days and nights '(Razi, 2005: 456-457). Here, drinking wine is also for "gaining knowledge" and "perceiving the spiritual truth", which is different from the "true festive wine drinking", and there is no traces of joy and pleasure in that, despite the fact that "true and natural wine" is used.

Furthermore, there are cases of wine drinking in the ancient Iran, which is different from all the three cases of mystic, true-festive and literary ones. This kind of drinking was a ritual of ancient Persians. "When they wanted to make an important decision, they would propose the issue in a gathering, while being drunk, and they would decide. The other day, in the sobriety, they will propose the same issue again, and will make the proper decision. Then, if their comments in drunkenness and sobriety were the same, they would act accordingly; otherwise they would refrain from such decision. Also, they would do this process, the other way round; which means firstly they would decide on some problems while being sober; and if their decisions in drunkenness was the same; they would practice it; otherwise the decision would be put aside." (Razi, 2011, 258-259). This kind of drinking is different from drinking at dawn and dusk, that were just for pleasing the body; because the mentioned type, deals with "deciding on important issues" in two moods of "with the presence of oneself" and "without the presence of oneself" which shows the accuracy in judgment and were not done for joy and pleasure, which is a significant matter.
Maybe, at the time of this kind of Iranian drinking, there had been some similar rituals in the Ancient Greece that has been always regarded as the cradle of philosophical ideas. The history of drinking in the Greek philosophy goes back to the Orphic rituals: "they have a custom called "Aeorga", which was somehow like "wine feast" and the aim of such festive was to redeem from the "cycle of birth" which was the same of Hindu's "Sensar". (Hooman, 1970: 76). This idea of redemption, has a philosophical origin, because it is a redemption from change and death.

These ancient world rituals are reflected in the literature and vernacular culture in another form, and each of them, represent the main idea, differently.

In Ferdowsi's Shahnameh, and in the story of "Bijan and Manizheh", when Keykhosro is talking with "Geev" about finding "Bijan", Ferdowsi depicts the use of "Nabid"[a wine made of date], without speaking about drinking and says:

And I want that goblet showing me the world

I will go to God and I will stand

And I will search all the seven worlds

And I will seek in every corner and border

And I will pay tribute to my fathers

The ones I love and the ones I have

And I will say where Bijan is

Which is obvious in the goblet

Then he came in Roman Attire

So that he could go before God

Roared before the Creator

First Admiring the Sun and the light

Requested from the Helper, Help

Complained about the Evil vices

Then, he returned from there happily

With that lucky crown on his head

A goblet of Nabid in has hand

Saw seven worlds in it

The time and the space of the high sky

Was obvious in that altogether

From fish to lamb all in all

Were visible in the goblet

(Ferdowsi, 2007: 566-566)

According to Mahdi Gharib's words, the edition and correcting the text of this Shahnameh was done on the basis of 10 versions, from the oldest recognized hand-written Shahnameh in the world and comparing it to the first and second versions of Moscow Shahnameh and also with Jalal Khaleghi-Motlagh version. In this text, Nabid goblet which Keykhosrow held in his hand to uncover the unknown mysteries of the worlds, is originally a "natural and true wine" but is not pleasing and enjoyable like the natural and true wines. Rather, it is a "Hikmah/philosophical" wine which makes the drinker conscious of the mysteries of the other lands, and is different from the mystic, true-festive and literary ones; in the wine mentioned, somehow the reason is its place and the knowledge is gained through the reason, rationality and experience.

Allameh Jafari, classifies Khayyam's Rubaiyat into four categories and about the third and fourth categories says: "the third category, are the rubaiayats in which Hedonistic ideas 
are propagated and Epicurean type of living is introduced. Some rubaiayats of these categories have useful contents such as relieving people from pains and hardships, and also about enjoying the legal pleasures which God has given to us. However, a significant part of these rubaiayat introduces pleasure as the purpose of the life or the thing which can make one unaware of the realities of life. The fourth category, are the rubaiayat whose contents that are irrational, considered with the common sense and the philosophy of Omar Khayyam's intellectual policy, and those are the rubaiayat which propagate nihilism and the absurdity of being" (Jafari, 1986:3). In order to clarify this issue, one should say that "the Epicurean philosophy has been accused of many libels and misunderstandings since its introduction, in such a way that the adjective "Epicurean" has been misused as equivalent of debauchery and libertinism!" (Pourhosseini, 2002: 33-34). These accusations to Epicure, has led to the notoriety of Epicureans, while the most remarkable features of those people were "simple" nutrition regime, contentment and complete reluctance toward worldly matters." (Pourhosseini, 2002: 28).

Saint Augustine who was a theist philosophers, and he can be regarded as the first theist of the ancient Greece, talks about the effects of Epicureanism on his ideas "I introspected by Epicurean influence, and there I recognized that if I had not had any belief in the immortality of the spirit, otherworldly rewards and punishment like Epicure, then I would propose the issue to myself, as such: If we were eternal and our life had continuance in the interactions of intuition and sense by myself, and I was not afraid of mortality, then I would not be blissful for good" (Pourhosseini, 2002: 31). This Epicure who was a role model for the first Greek theist philosopher, and believed in the immortality of the spirits and the action rewards, cannot be the propagator of such libels like debauchery.

Khayyam in the following rubaee, depicts the failure of his "thoughtfulness" and since "the truth" does not reveal itself to him, he inevitably resorts to "virtual hikmah/philosophical wine" so that he can redeem himself. This wine has more specific meaning than the "literary/figurative" wine. If Khayyam is a drunkard, how can he order his thoughts in the form of rubaee, such artistically?

As there is not truth and certitude at hand

One cannot waste his life in hope and doubt

Behold! Not to let the wine chalice off hand

One dies in ignorance, either sober or drunk

(Ghani, 2001:32)

This wine chalice is the very idea of "hikmah/philosophical wine" which resolves doubts, because if man cannot uncover the unknowns and is ignorant of the truths, is equal to the drunk and unaware person. Certainly, the use of "wine chalice" in this Khayyam's poem is essentially different from the "natural and true-festive wine", "literary/figurative" and "mystic" ones.

Also, the contemporary poets have extremist non-Epicurean or hedonistic ideas towards Khayyam and regard the "Khayyami wine" as "mystic" and "philosophical" implications:

Me who I am drown in the colorless sea of love

How can a colorful wine take me to my wish?
The medicine that heals my pain is Khayyami wine

Not anything filthy evil-colored of good origin

Where is that Hafez-like companion in the way to tavern?

With whom I will take wine, whatever will be, will be!

(Musavi-Garmarudi, 2004: 42)

Mr. Khorramshahi's idea about wine is "Hafez researchers have said this thing again and again that we have two wines in Hafez's poetry: grape wine and mystic wine. Or this idea has been frequently touched upon that we have two kinds of beloved in Hafez's Divan: earthly and divine-mystic. However, I think that there is a third type of wine and beloved in Hafez's poems and I believe that most Hafez's poems revolve over this third type, which is the "literary or figurative" wine and beloved" (Khorramshahi, 2004: 194). Now, considering the evidence and the use of "perception and knowledge" and "uncovering the unknowns", etc. one can add another wine called "hikmah-related/philosophical wine" which can be classified into two groups of "natural hikmah/philosophical wine" like Keykhosro's wine in Bijan and Manizhes' story, or "Goshtasbi wine" in Zartosht and magus story and "virtual hikmah/philosophical wine" like Khayyam's poems and Khayyami thoughts.

In case of the meaning difference of "virtual hikmah/ philosophical wine" and "literary/figurative wine" one can say, the use of virtual hikmah/philosophical wine is to relief the poet from the confusing thoughts about the causality of the being and philosophical ideas - in short, it is more specific- and the meaning of literary/figurative wine is more general, and there is "natural-festive wine" which is immoral.

Here, this question can be asked that are all the poets using philosophical words in their poem, familiar with philosophy? The answer is that if the aim of "philosophy" is thinking, then all the poets have written poems out of thoughts, but if we mean a specific philosophical school or idea, then one cannot easily confirm or reject this issue, since most great Persian poets of all times, have been familiar with philosophy, hikmah, sophistry, and other sciences, and one cannot doubt such fact. Also, most poets were educated and were experts in the sciences of their times and every poet who has been more knowledgeable in case of philosophy and hikmah, has had more elaborate poems and more solid words; and has been able to make his poems more popular, by using hikmah-related, philosophical, literary techniques. However, we cannot claim that a given poet or author, has been affected by a certain philosopher or hakim. In any case, "it has been said about the great philosophers that whose influences and traces are such prevalent and extensive that we think with their thoughts, even without mentioning their names" (Mosayyebi, 2013:35). Nima Youshij, in this case says:

Firstly, by means of sophistry, my concepts were formed Then by philosophical ways, I was condemned by mind In sum, I continued this dialogue until my heart

Came in between and uncovered me all

(Youshij, 2001:696)

This rubaee and suchlike shows that if Nima had not been familiar with philosophy masterfully, he had some knowledge of it, and this knowledge of hikmah and philos- 
ophy was itself the solution to many intellectual issues or he had intellectual concerns about such things in his daily life.

Akhavan, in his poems, regards himself as the follower of Hafez and Khayyam and uses these two poets' words and expression in his poems, which shows their influence on Akhavan's diction. Hence, Akhavan in his youth, had critical ideas about "being" like Khayyam and would question "nature's function" and challenged with many whys and problems. However, some of these ideas must not be considered as the signs of his weak morals.

Behold that of the gone in the history

There is nothing left, except a line of news

We are all playthings of the wind

None is eternal in this road

Omid! Enough of these heart-rending whines

No dawn after the night for us, the miserables

(Akhavan, 2004: 27-28)

Akhavan sees himself facing many "whys" and cannot find proper answers for those questions. Therefore, he considers himself miserable and his ideas cannot be thought as extremist Epicurean or secular existentialist and hedonistic.

Also in order to reach the truth - not of mystic type- Akhavan, turns to "wine" in his poems and with our knowledge of Akhavan's life and record, we do not expect from him, Hafez or Molavi type of mysticism, and we cannot regard the "wine" used in his poems, as a mystic element. In addition, this wine, is not "literal/figurative" type either, since with it, the poet has not made the speech figurative, but it has a certain meaning. So this wine, except "true or virtual hikmah/philosophical wine" which can be used for freeing oneself from confusion and truth perception, what other type can be?

Fear not we of wine, as it is not a breath

That we take without a drunken whine

Absolute confused are we, and in this oasis of wonder

We are wise enough to decide to go crazy

As we cannot reach the realm of the truth

No choice we have rather than going for fiction

(Akhavan, 2004:75)

\section{True and natural festive wine}

In case of "true and natural festive wine", we should say that "in its nature, this entity deals with drunkenness, fostering bestial characteristics of the inciting nafs (an-nafs al-'ammārah), being immersed in lust and passions which is an objective, material and external thing.

In our time, in order to kill the pain of solitude, emotional break-down, and religious confusion, debauchery and cases like these, people resort wine and other alcoholic drinks. "In the developed countries, the emotions are extremely exaggerated and by means of resources and things such as alcohol, narcotics, medicines, food, real sexual relationships and virtual sexual relationships, all the joy and pleasure that religious and social methods can give, are transferred to sensual issues and feelings" (Amir-Rahimi, 2013:11). These are just done to let the people be happy for a while; the happiness that can be regarded as the influence of extreme Epicureanism.

Although the poems written after the Islamic Revolution in Iran, are conservative and committed to the ideals of the Revolution, one can see some aspects of the true and festive wine in some parts of the poems of the contemporary poets. In the following instance, Akhavan speaks simply of "love, youth, pleasure and wine" and depicts the youth life as follows:

And when comes the tale of love and drunkenness

It is all yearning and burning, if any veils remained of shame

It is love, youth, wine and a beautiful woman

And what a seductive woman, love and wine!

(Akhavan, 2004: 86)

\section{Mystic wine}

In Iraqi ${ }^{1}$ 's time, with the entrance of Sufism into poetry, the content of the poetical forms of ghazal and rubaee changed basically, and "wine" and "love" as the flavors of the mysticism in this era, and their belongings such as tavern, magus, cup and chalice were used extensively in the poems and a novel epoch began by this diction.

"Pir"" is the guide of "Salik" in the way to reach the "truth"; after "Pir", Salik's teachers are love and wine. Love will reduce the belongings from man and eliminates him into the "truth", but "wine" is better than love, as at the time of "reasoning", "no mystical intuition" will occur to man and only in "trance" and "drunkenness", this intuition occurs. This is in contrast with rationalist philosophy which says "rational intuition" is innate in humankind.

When Sanaee speaks of "mystic wine", he uses the other related words such as Saqi, Jaam (Chalice), Tavern and forms a series of related and associated expressions:

Oh Saqi! Rise and pour wine in the chalice

Rest in the desolate tavern

Burn the sky with the cleaning fire

Pour dark soil on the head of days

(Foruzanfar, 1996:472)

Sanaee's mystic wine is for mystic "trance" so that by which, the pride and darkness of the spirit, are cleansed and the rebellious self is tamed.

Came the time when we shall get chalice

Sing aloud songs like lovers

In the way of love with wine

We shall clean the dirt off our souls

(Ibid, 1996: 453)

The mystic wine of Molavi like Sanaee's, is for redeeming from "selfishness", "reaching and meeting" the true beloved, and emptying oneself from lust and passions:

"If I am drunken and debauched, I am not like you drunken of wine

Neither I am from earth, nor water, not I am from this time

$1 \quad$ Fakhr-al-Din Iraqi.

2 The Oldman; Teacher.

3 The Truth-seeker. 
What knows the humankind's mind from this breath?

That I hide from the worldly veil to two-hundred veils (Nicholson, 2004:22)

However, Hafez talks about this "wine and beloved" with an ambiguous and mysterious language and conceals the real meaning so that the one who is knowledgeable of the heart's secret, perceive the truth and the others also could gain it.

He who has the chalice in his hand

Is the king of Jam (Sees all the world) all the time

For these kinds of Hafez's poems, considering the solid bridge between the true love and the virtual one, one should think if the various meanings of the words in his poems.

\section{Literal/figurative wine}

In the poetry, when the word "wine" is used for figurative uses- and not for any other purposes- or if the poet does not mean the mystic and natural wine, then we can call that wine, figurative or literary.

Akhavan, in the following verses, by using "wine" does not want to imply "mystic", "joyful" "freeing from ontological thoughts", and other purposes; rather, he wants to imitate Hafez in using figurative and rhetoric language to make his words more pleasing.

The other night, Peris unbound my wings

Kissed me and with wine, they stole me from the tavern

The singers of the dancehall of the heaven

While dancing, sang me a melodious song

(Akhavan, 2004:19)

Now, comparing the many types of poetical wines, one can say that their usages in the poems, cannot be always for lust and pleasure.

\section{CONCLUSION}

Wine in the Persian poetry, has been divided into three categories of mystic, true and figurative/literary. The mystic wine can be seen in the poems of poets such as Sanaee, Molavi, Hafez, the Islamic Revolutionary poets and other mystics. Figurative/literary wine is just for literary arrangement of the poems; used by most poets for making the poem more pleasing.

In case of the meanings of "true and natural festive wine", considering its various functions in the poetry, one should be more careful to identify the main purpose of the poet and author so that he can make a proper judgment. Most literary theoreticians, believe that the origin of such "wine" in the post-Islamic poetry, was the Khorasani style of poetry; though, in other eras, this particular meaning of wine has been used. Also, many believe that this meaning of wine in poetry, has some similarities with "drinking wine" in the Hedonistic and extreme Epicurean cults, since the followers of such cults and philosophical schools, practice pleasing themselves from earthly pleasures and even for getting such joys and pleasures, they resort to "narcotics and intoxicants".

However, in the Persian literature and philosophy, "natural and true wine" has been used for other purposes rather than just giving pleasure, such as the usage of wine in the story of Bijan and Manizheh, Zartosht and Goshtasb, Haoma juice drinking for gaining knowledge and intuition. In such instances, drinking was not of extreme Epicurean and Hedonistic joys and pleasures and maybe the poets' familiarity with those subjects, was the cause of using that kind of "wine" in the poems. In this regard, we can name these kinds of usages in the Persian poetry as "hikmah/philosophical wine".

Finally, it is suggested that more consideration and thought be focused on the various usages of "natural wine", and its meanings. Also, it is better to distinguish Khayyami wine and thought from the Hedonistic and extreme Epicurean ideas. Furthermore, it is suggested to avoid labeling such thoughts as "unethical", only because they sometimes question rationalism or sometimes approve it.

\section{REFERENCES}

Akhavan-Saless, Mahdi (Omid), Arqanun (2004), 12 ${ }^{\text {th }}$ Ed, Morvarid Publication, Tehran.

Amir-Rahimi, Reza - Translator- Looking for Spinoza, Damasio, Antonio (2013), Ganjineh, Tehran.

Bamdad, Mahmoud, Hafezology (1959), $2^{\text {nd }}$ Ed, Ettehad, Tehran.

Behrouzi, Ali- Translator- On Descartes (2014), Garrett, Thomson: Tarh-e-No, Tehran.

Pourhosseini, Seyyed Abolghasem- Translator- Epicure's Philosophy, Berne, Jean (2002), $2^{\text {nd }}$ Ed, Amirkabir, Tehran.

Kharazzi, Mohsen- Calligrapher- (2001) Roudaki, Jafar ibn Mohammad, Divan, $3^{\text {rd }}$ Ed, Ganjineh, Tehran.

Jafari, Mohammad-Taghi, Analyzing Khayyam's Characteristics (1986), Keihan, Tehran.

Khorramshahi, Bahauddin, Hafez-nameh (2004), Scientific and Cultural, Tehran.

Razzi, Hashem, Khosravani Hikmah, (2005), Behjat, Tehran

Iranian Religion and Culture Before Zartosht (2011), Sokhan, Tehran.

Zonnur, Rahim, Looking for Hafez (1993), $1^{\text {st }}$ Vol, $3^{\text {rd }}$ Ed, Zavvar, Tehran.

Sanei Darreh-Bidi, Manoucher, Basic Philosophical Ideas (2005), Amirkabir, Tehran.

Ghani, Ghassem, Khayyam's Rubaiyat (2001), Khayyam, Omar ibn Ibrahim, Edited By Forughi, Mohammad Ali, $3^{\text {rd }}$ Ed: Ganjineh, Tehran.

Ferdowsi, Abolghassem (2007), Shahnameh, $1^{\text {st }}$ Vol- Editor- Gharib, Mahdi, Tehran: Doostan.

Forouzanfar, Badiozzaman (1996), Sanaee- Ghaznavi, Abolmajd Bani Adam: Negah, Tehran.

Mortazavi, Manouchehr, Hafez's School (2005), $1^{\text {st }}$ and $2^{\text {nd }}$ Vol: Toos, Tehran.

Mashayekhi, Reza, Aristotle, Ethics (2011), Negah, Tehran.

Mosayyebi, Reza-Translator- Kant's Principle of Justice as Categorical Imperative of Law, Hoffe, Otfreid, (2013), Ney, Tehran.

Musavi-Garmarudi, Ali, The Green Voice: Selected by the 
Poet from all His Poem Books, (2004), Ghadyani, Tehran. Hooman, Mahmoud, The History of Philosophy (1969), Nicholson, Reynold \& Arberry, John- Translator- (2004) $\quad 1^{\text {st }}$ Vol: Tahouri, Tehran.

Mohammad ibn Mohammad Molvai, Jalaludin, Hermes, Youshij, Nima (Ali Esfandiari), Nima Youshij Anthology Tehran. (2001), $2^{\text {nd }}$ Ed: Eshareh, Tehran. 